\title{
FAKTOR-FAKTOR YANG BERHUBUNGAN DENGAN PEMBERIAN IMUNISASI CAMPAK PADA BAYI DI DESA PEMATANG TEBIH UJUNGBATU TAHUN 2014
}

\author{
Dwi Sapta Aryantiningsih
}

\begin{abstract}
ABSTRAK
Imunisasi adalah suatu upaya mendapatkan kekebalan tubuh terhadap suatu penyakit dengan memasukkan kuman atau kuman yang sudah dilemahkan atau sudah dimatikan (Marimbi,2010). Campak adalah penyakit menular, disebabkan oleh virus Morbili. Pemberian imunisasi campak agar anak mendapatkan kekebalan terhadap penyakit campak secara aktif. Desa Pematang Tebih merupakan desa dengan cakupan imunisasi campak yang paling rendah di Wilayah Kerja Puskemas Ujung Batu dengan pencapaiannya yaitu tahun 2011(100\%), tahun $2012(95,1 \%)$ dan tahun 2013 sebesar (91,9\%). Tujuan penelitian ini adalah untuk mengetahui faktor-faktor yang berhubungan dengan perilaku ibu dalam pemberian imunisasi campak pada bayi di Desa Pematang Tebih Ujungbatu Tahun 2014. Jenis penelitian yaitu analitik kuantitatif dengan pendekatan cross sectional. Populasinya yaitu seluruh ibu yang mempunyai bayi yang berumur 9 sampai 12 bulan di Desa Pematang Tebih sejumlah 108 orang dengan teknik proportional stratified random sampling. Pengumpulan data primer dengan menggunakan kuesioner. Analisa data yaitu univariat dan bivariat. Hasil penelitian yaitu ada hubungan antara pendidikan ibu $(\mathrm{POR}=3,179)$, status pekerjaan ibu $(\mathrm{POR}=0,073)$, status ekonomi $(\mathrm{POR}=11,200)$, sarana dan prasarana $(\mathrm{POR}=6,900)$, dukungan keluarga $(\mathrm{POR}=6,838)$ dan dukungan tenaga kesehatan $(\mathrm{POR}=9,562)$ dengan pemberian imunisasi campak pada bayi. Disarankan agar petugas kesehatan meningkatkan upaya promotif dalam upaya peningkatan pengetahuan dan kesadaran masyarakat tentang imunisasi campak pada bayi.
\end{abstract}

Kata Kunci : Pendidikan, Status pekerjaan, status ekonomi, sarana dan prasarana, dukungan keluarga, dukungan tenaga kesehatan, Pemberian Imunisasi Campak.

\section{PENDAHULUAN}

Penyakit campak merupakan salah satu penyebab kematian pada anak-anak di seluruh dunia yang meningkat sepanjang tahun (Kemenkes RI, 2010). Indonesia adalah negara keempat terbesar penduduknya di dunia yang memiliki angka kesakitan campak sekitar 1 juta pertahun dengan 30.000 kematian, yang menyebabkan Indonesia menjadi salah satu dari 47 negara prioritas yang diidentifikasi oleh World Health Organization (WHO) dan United Nations International Children's Emergency Fund (UNICEF) untuk melaksanakan akselerasi dalam rangka mencapai eliminasi campak (Kemenkes RI, 2013).

Berdasarkan data dari subdit surveilans pada tahun 2011 terdapat 23.282 kasus suspek campak, sedangkan pada tahun 2012 terdapat 15.865 kasus suspek campak. Hal ini menunjukkan kasus campak di Indonesia masih cukup tinggi (Kemenkes RI, 2013). Menurut Undang-Undang Kesehatan Nomor 36 Tahun 2009 Pasal 132 ayat
3 yang berbunyi "Setiap anak berhak memperoleh imunisasi dasar sesuai dengan ketentuan yang berlaku untuk mencegah terjadinya penyakit yang dapat dihindari melalui imunisasi. Hasil estimasi WHO tahun 2011 terhadap kematian akibat Penyakit yang Dapat Dicegah Dengan Imunisasi (PD3I) dalam satu tahun tidak kurang dari 540.000 anak karena campak. Dari data diatas dapat dilihat bahwa kematian balita akibat PD3I terbesar adalah karena campak.

Kejadian penyakit campak sangat berkaitan dengan keberhasilan program imunisasi campak. Indikator yang bermakna untuk menilai ukuran kesehatan masyarakat di negara berkembang adalah imunisasi campak. Imunisasi campak merupakan imunisasi untuk mencegah terjadinya penyakit campak pada anak karena penyakit ini sangat menular (Kemenkes RI, 2013).

Puskesmas Ujungbatu, mempunyai 5 Desa. Dari 5 Desa yang ada di Ujungbatu cakupan imunisasi campak yang paling rendah dan terjadi 
penurunan tiap tahunnya terdapat di Desa Pematang Tebih. Tahun 2011 sebesar 100\%, tahun 2012 sebesar 95,1\% dan tahun 2013 sebesar 91,9\% dengan Standar Pelayanan Minimal (SPM) Puskesmas Ujungbatu yaitu $95 \%$.

Dalam hal ini peran orangtua khususnya ibu menjadi sangat penting. Demikian juga tentang pengetahuan, sikap, kepercayaan, pendidikan, pekerjaan, status ekonomi, dukungan keluarga, sarana prasarana dan dukungan tenaga kesehatan akan sangat mempengaruhi kepatuhan pemberian imunisasi dasar pada bayi dan anak, sehingga dapat mempengaruhi status imunisasinya.

Berdasarkan data diatas maka peneliti merasa tertarik melakukan penelitian tentang faktorfaktor yang berhubungan dengan perilaku ibu dalam pemberian imunisasi campak pada bayi di Desa Pematang Tebih Ujungbatu Tahun 2014.

\section{METODE PENELITIAN}

Jenis penelitian ini adalah penelitian analitik kuantitatif dengan desain penelitian cross sectional untuk mengetahui faktor-faktor yang berhubungan dengan perilaku ibu dalam pemberian imunisasi campak pada bayi. Penelitian ini dilaksanakan di Desa Pematang Tebih Ujungbatu. Penelitian ini dilaksanakan dari bulan Januari - Mei 2014. Populasi dalam penelitian ini adalah seluruh ibu yang mempunyai bayi yang berumur 9 sampai 12 bulan di Desa Pematang Tebih Ujungbatu yaitu berjumlah 196 orang. Besar sampel yang diteliti yaitu 108 responden. Tekhnik sampling dengan proporsional stratified random sampling yaitu membagi secara proporsional pada 6 posyandu. Instrument penelitian menggunakan kuesioner dengan menggunakan data primer. Tekhnik pengumpulan data dengan editing, coding, tabulating, processing, dan cleaning. Analisis data secara univariat dan bivariat.

\section{HASIL DAN PEMBAHASAN}

\section{Analisis Univariat}

Hasil analisis univariat diperoleh proporsi pemberian imunisasi campak pada bayi yaitu 53 orang $(49,1)$ dan untuk variabel independent dapat dilihat pada tabel berikut:

Tabel. 1. Distribusi Frekuensi Responden Berdasarkan Variabel Independen Di Desa Pematang Tebih Tahun 2014

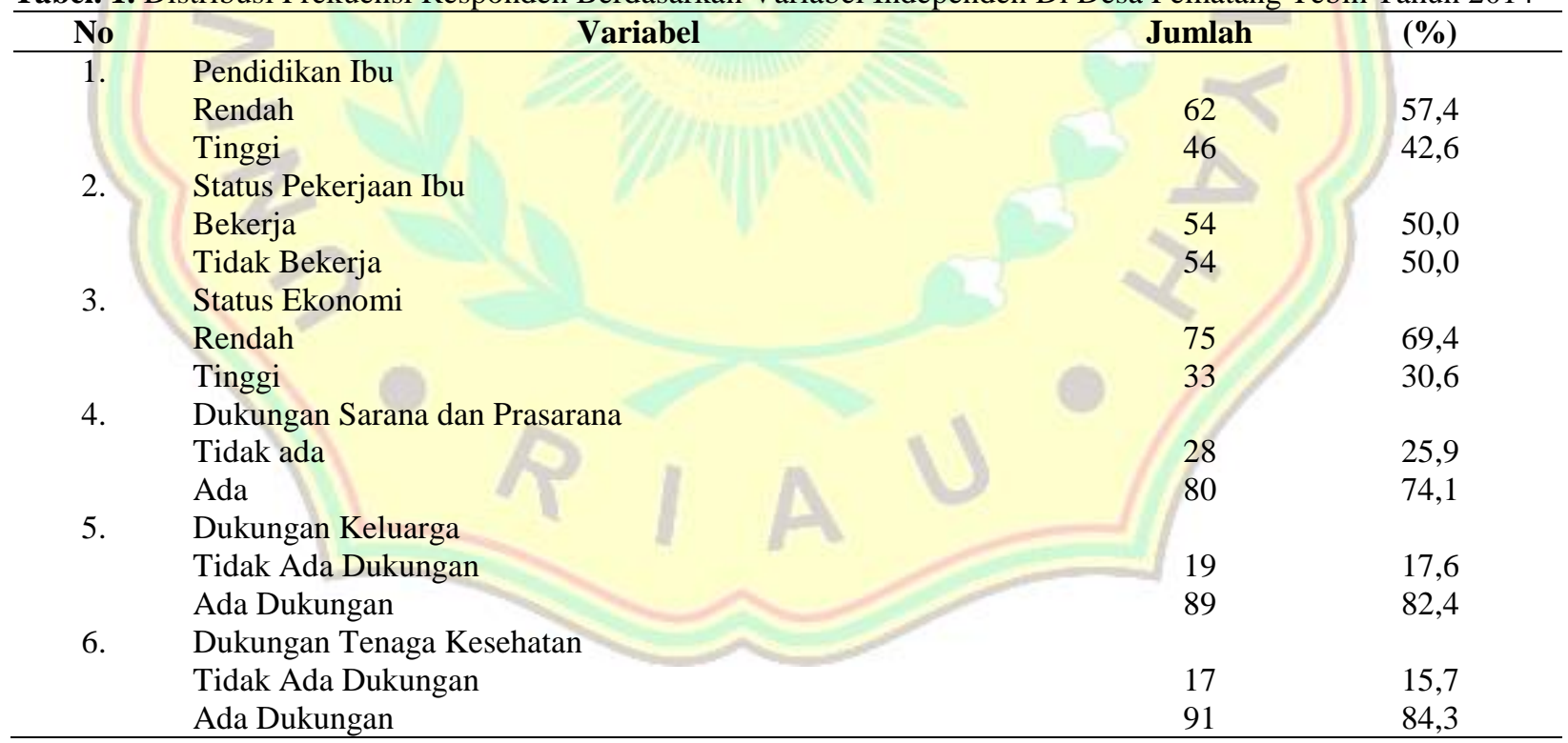

Sumber: Analisis Data Penelitian, 2014

Dari tabel 1 diatas, dapat dilihat pendidikan ibu kategori rendah yaitu 62 orang $(57,4 \%)$, ibu yang tidak bekerja yaitu 54 orang $(50,0 \%)$, status ekonomi keluarga kategori rendah yaitu 75 orang $(69,4 \%)$, tidak adanya dukungan sarana dan prasarana yaitu 28 orang $(25,9 \%)$, tidak adanya dukungan dari keluarga yaitu 19 orang $(17,6 \%)$, tidak adanya dukungan dari tenaga kesehatan yaitu 17 orang $(15,7 \%)$. 


\section{Analisis Bivariat}

Tabel. 2. Distribusi Frekuensi Variabel Independen dengan Pemberian Imunisasi Campak Pada Bayi di Desa Pematang Tebih Tahun 2014

\begin{tabular}{|c|c|c|c|c|c|c|c|c|c|}
\hline \multirow[b]{3}{*}{ No } & \multirow{3}{*}{$\begin{array}{c}\text { Variabel } \\
\text { Independen }\end{array}$} & \multicolumn{4}{|c|}{ Pemberian Imunisasi } & \multirow{2}{*}{\multicolumn{2}{|c|}{ Total }} & \multirow{3}{*}{ P value } & \multirow{3}{*}{ POR } \\
\hline & & \multicolumn{4}{|c|}{ Campak } & & & & \\
\hline & & \multicolumn{2}{|c|}{ Tidak } & \multicolumn{2}{|c|}{$\mathbf{Y a}$} & f & \multirow{2}{*}{$\%$} & & \\
\hline \multirow[t]{3}{*}{1.} & Pendidikan Ibu & & & & & & & \multirow{3}{*}{0,007} & \multirow{3}{*}{3,179} \\
\hline & Rendah & 39 & 62,9 & 23 & 37,1 & 62 & 100,0 & & \\
\hline & Tinggi & 16 & 34,8 & 30 & 65,2 & 46 & 100,0 & & \\
\hline \multirow[t]{3}{*}{2.} & Status Pekerjaar & & & & & & & \multirow{3}{*}{0,000} & \multirow{3}{*}{0,073} \\
\hline & Bekerja & 43 & 79,6 & 11 & 20,4 & 54 & 100,0 & & \\
\hline & Tidak Bekerja & 12 & 22,2 & 42 & 77,8 & 54 & 100,0 & & \\
\hline 3. & Rendah & 50 & 66,7 & 25 & 33,3 & 75 & 100,0 & 0,000 & 11,200 \\
\hline \multirow[t]{6}{*}{4.} & \multicolumn{5}{|c|}{ Dukungan Sarana dan Prasarana } & \multirow{3}{*}{$\begin{array}{l}28 \\
80\end{array}$} & \multirow{3}{*}{$\begin{array}{l}100,0 \\
100,0\end{array}$} & \multirow{6}{*}{$\begin{array}{l}0,000 \\
0,003\end{array}$} & \multirow{3}{*}{6,900} \\
\hline & Tidak Ada & 23 & 82,1 & 5 & 17,9 & & & & \\
\hline & & 32 & 40,0 & 48 & 60,0 & & & & \\
\hline & Dukungan Kelu & & & & & & & & \multirow{3}{*}{6,838} \\
\hline & Tidak Ada & 16 & 84,2 & 3 & 15,8 & 19 & 100,0 & & \\
\hline & Ada & 39 & 43,8 & 50 & 56,2 & 89 & 100,0 & & \\
\hline \multirow[t]{3}{*}{6.} & Dukungan Tena & Kesel & & & & & & \multirow{3}{*}{0,002} & \multirow{3}{*}{9,562} \\
\hline & Tidak Ada & 15 & 88,2 & 2 & 11,8 & 17 & 100,0 & & \\
\hline & Ada & 40 & 44,0 & 51 & 56,0 & 91 & 100,0 & & \\
\hline
\end{tabular}

Berdasarkan tabel 2 dapat dilihat bahwa variabel yang berhubungan dengan perilaku dalam pemberian imunisasi campak pada bayi adalah pendidikan ibu, status pekerjaan ibu, status ekonomi, dukungan sarana dan prasarana, dukungan keluarga, dukungan tenaga kesehatan. Jika dilihat dari pendidikan ibu, diperoleh POR=3,179, hal ini dapat disimpulkan bahwa ibu yang berpendidikan rendah, bayinya berisiko 3,179 kali tidak mendapatkan imunisasi campak dibandingkan dengan ibu yang berpendidikan tinggi. Jika dilihat dari status pekerjaan ibu, diperoleh POR=0,073, hal ini dapat disimpulkan bahwa ibu yang bekerja, bayinya berisiko 0,073 kali tidak mendapatkan imunisasi campak dibandingkan dengan ibu yang tidak bekerja. Jika dilihat dari status ekonomi, diperoleh POR= 11,200 , hal ini dapat disimpulkan bahwa keluarga dengan status ekonomi rendah, bayinya berisiko 11,2 kali tidak mendapatkan imunisasi campak dibandingkan dengan keluarga dengan status ekonomi tinggi.

Jika dilihat dari dukungan sarana dan prasarana, diperoleh $\mathrm{POR}=6,900$, hal ini dapat disimpulkan bahwa tidak adanya dukungan sarana dan prasarana pada keluarga, bayinya berisiko 6,900 kali tidak mendapatkan imunisasi campak dibandingkan dengan adanya dukungan sarana dan prasarana pada keluarga. Jika dilihat dari dukungan keluarga, diperoleh $\mathrm{POR}=6,838$, hal ini dapat disimpulkan bahwa tidak adanya dukungan keluarga, bayinya berisiko 6,838 kali tidak mendapatkan imunisasi campak dibandingkan dengan adanya dukungan keluarga. Jika dilihat dari dukungan tenaga kesehatan, diperoleh POR $=9,562$, hal ini dapat disimpulkan bahwa tidak adanya dukungan tenaga kesehatan, bayinya berisiko 9,562 kali tidak mendapatkan imunisasi campak dibandingkan dengan adanya dukungan tenaga kesehatan. 


\section{Pembahasan}

Dari hasil penelitian menunjukkan bahwa responden memiliki latar belakang pendidikan yang relatif rendah yaitu tidak sekolah, tidak tamat SD, SD, dan SMP mencakup sebanyak 62 orang $(57,4 \%)$. Hasil analisis bivariat didapatkan POR $=3,179$ artinya responden yang memiliki tingkat berpendidikan rendah berpeluang 3,179 kali untuk tidak memberikan imunisasi campak pada bayi. Hal ini sesuai dengan penelitian Nuraprilyanti (2009) yang juga mengatakan adanya hubungan antara tingkat pendidikan ibu dengan perilaku mengimunisasi pada bayinya.

Semakin tinggi pendidikan seseorang, semakin mudah orang tersebut untuk menerima informasi, sebaliknya tingkat pendidikan yang rendah akan menghambat perkembangan dan sikap seseorang terhadap nilai-nilai yang baru diperkenalkan. Seseorang dengan tingkat pendidikan yang terlalu rendah akan sulit dalam menerima pesan dan informasi yang disampaikan (Djaiman, 2002)

Dari hasil penelitian menunjukkan bahwa status pekerjaaan responden yang bekerja yaitu 54 orang $(50 \%)$. Hasil analisis bivariat didapatkan $\mathrm{POR}=0,073$, hal ini dapat disimpulkan bahwa ibu yang bekerja, bayinya berisiko 0,073 kali tidak mendapatkan imunisasi campak dibandingkan dengan ibu yang tidak bekerja.

Ibu yang sibuk dengan kegiatan atau pekerjaan sehari-hari akan memiliki waktu yang lebih sedikit untuk memperoleh informasi sehingga pengetahuan yang diperoleh juga berkurang.

Dari hasil penelitian menunjukkan bahwa mayoritas status ekonomi responden adalah rendah yaitu 75 orang $(69,4 \%)$. Hasil analisis bivariat didapatkan $\mathrm{POR}=11,200$ yang berarti keluarga dengan status ekonomi yang rendah bayinya berisiko 11,2 kali tidak diimunisasi dibandingkan dengan keluarga dengan status ekonomi yang tinggi. Hal ini didukung oleh penelitian yang dilakukan oleh Mardani (2008) tentang faktor yang mempunyai kaitan dengan kelengkapan imunisasi dasar pada bayi, yaitu tingkat penghasilan keluarga.
Pendapatan keluarga memadai akan menunjang tumbuh kembang anak. Karena orang tua dapat menyediakan semua kebutuhan anak baik primer maupun sekunder (Soetjiningsih, 2004).

Dari hasil penelitian didapatkan bahwa ketersediaan sarana dan prasarana yang ada, yaitu sebanyak 80 orang $(74,1 \%)$. Berdasarkan hasil analisis bivariat didapatkan $\mathrm{POR}=6,900$ yang berarti keluarga yang tidak ada dukungan sarana dan prasarana bayinya berisiko tidak diimunisasi 6,9 kali dibandingkan dengan keluarga yang ada dukungan sarana dan prasarana. Hal ini sesuai dengan penelitian Nuraprilyanti (2009) yang juga mengatakan adanya hubungan antara sarana atau fasilitas pelayanan imunisasi dengan perilaku ibu dalam pemberian imunisasi campak pada bayi.

Untuk berperilaku sehat, masyarakat memerlukan sarana dan prasarana pendukung. Sarana pelayanan kesehatan bagi masyarakat terdiri dari rumah sakit, puskesmas, pustu, poliklinik, posyandu, polindes, praktek dokter/ bidan swasta dan sebagainya (Notoatmodjo, 2007).

Dari hasil penelitian menunjukkan bahwa responden yang tidak mendapatkan dukungan keluarga sebanyak 19 (17,6\%). Hasil analisis bivariat, diperoleh $\mathrm{POR}=6,838$, hal ini dapat disimpulkan bahwa tidak adanya dukungan keluarga, bayinya berisiko 6,838 kali tidak mendapatkan imunisasi campak dibandingkan dengan adanya dukungan keluarga.

Seseorang membutuhkan dukungan untuk berperilaku kesehatan, dengan adanya dukungan dari lingkungan sekitar akan memudahkan seseorang dalam melakukan perubahan perilaku (Notoatmodjo, 2005).

Dari hasil penelitian menunjukkan bahwa responden yang tidak mendapatkan dukungan tenaga kesehatan sebanyak 17 orang $(15,7 \%)$. Hasil analisis. bivariat didapatkan POR=9,562 artinya keluarga yang tidak memiliki dukungan tenaga kesehatan bayinya berisiko 9,562 kali untuk tidak mendapatkan imunisasi campak dibandingkan sebaliknya. Dukungan tenaga kesehatan merupakan faktor yang mendorong atau memperkuat terjadinya perilaku. Kadangkala seseorang tahu dan mampu untuk 
berperilaku tetapi tidak melakukannya. Hal ini dapat dipengaruhi oleh beberapa faktor salah satunya dukungan sosial yaitu dukungan tenaga kesehatan (Notoatmodjo,2005).

Hal ini sesuai dengan penelitian Nuraprilyanti (2009) yang juga mengatakan adanya hubungan antara dukungan tenaga kesehatan dengan perilaku mengimunisasi pada bayinya.

\section{KESIMPULAN}

Dari hasil penelitian dapat disimpulkan bahwa:

1. Proporsi pemberian imunisasi campak pada bayi yaitu 53 orang $(49,1)$.

2. Ada hubungan antara tingkat pendidikan dengan pemberian imunisasi campak pada bayi dengan $\mathrm{POR}=3,179$.

3. Ada hubungan antara tingkat pekerjaan dengan pemberian imunisasi campak pada bayi dengan $\mathrm{POR}=0,073$.

4. Ada hubungan antara status ekonomi dengan pemberian imunisasi campak pada bayi dengan $\mathrm{POR}=11,200$.

5. Ada hubungan antara dukungan sarana dan prasarana dengan pemberian imunisasi campak pada bayi dengan $\mathrm{POR}=6,900$.

6. Ada hubungan antara dukungan keluarga dengan pemberian imunisasi campak pada bayi dengan $\mathrm{POR}=6,838$.

7. Ada hubungan antara tenaga kesehatan dengan pemberian imunisasi campak pada bayi dengan $\mathrm{POR}=9,562$.

Oleh karena itu dapat disarankan agar pihak Puskesmas lebih meningkatkan upaya promotif melalui penyuluhan-penyuluhan kesehatan khususnya imunisasi campak dalam upaya peningkatan pengetahuan dan kesadaran masyarakat akan pentingnya imunisasi campak pada bayi.

\section{DAFTAR PUSTAKA}

Arikunto. 2006. Prosedur penelitian suatu pendekatan praktik. Jakarta: Rineka Cipta.

Djaiman, S. 2002. Faktor-faktor yang mempengaruhi balita berkunjung ke Posyandu. http://www.litbangkes.com tanggal 7 januari 2014.
Friedman. 2004. Keperawatan Keluarga. Jakarta: EGC.

Hidayat, A. A. 2007. Metode penelitian kebidanan teknik analisis data. Jakarta: Salemba Medika.

Kartono. 2006. Perilaku Manusia. Jakarta: ISBN.

Kemenkes RI. 2010. Pedoman Pelaksanaan Kampanye Imunisasi Campak dan Polio Tambahan Tahun 2009-2011. Jakarta: Ditjen PP \& PL Kemenkes RI.

Kemenkes RI. 2013. Petunjuk teknis introduksi imunisasi DPT-HB-Hib (Pentavalen) pada bayi dan pelaksanaan imunisasi lanjutan pada anak batita. Jakarta: Ditjen PP \& PL Kemenkes RI.

Kementrian Tenaga Kerja dan Transmigrasi. 2014. Daftar Upah Minimum Propinsi UMP/UMR 2014 Terbaru. Diperoleh Tanggal 06 Maret 2014 dari http://www. Informasi terbaru .web.id/2013/11/ daftarupah-minimum-propinsi-umpumr.html.

Maryunani, A. 2010. Ilmu kesehatan anak dalam kebidanan, Jakarta: Penerbit CV. Trans Info Media.

Marimbi, H. 2010. Tumbuh kembang, status gizi, dan imunisasi dasar pada balita. Jakarta: Nuha Medika.

Medical Record Puskesmas Ujungbatu.. 2013. Angka prevalensi campak. Ujungbatu: Puskesmas Ujungbatu.

Muslihatun, W.N. 2010. Asuhan neonatus bayi dan balita. Yogyakarta: Fitramaya.

Proverawati, A. 2010. Imunisasi dan vaksinasi. Yogyakarta: Nuha Medika.

Notoatmodjo, S. 2003. Pengantar pendidikan kesehatan dan ilmu perilaku kesehatan. Jakarta: Rineka Cipta.

2003. Ilmu kesehatan masyarakat: prinsip-prinsip dasar. Jakarta: Rineka Cipta.

2005. Metodologi penelitian kesehatan. Jakarta: Rineka Cipta.

2007. Promosi kesehatan teori dan aplikasinya, Jakarta: PT Rineka Cipta.

Pusat Bahasa Departemen Pendidikan Nasional. 2003. Kamus Besar Bahasa Indonesia. Jakarta: Balai Pustaka. 
Ranuh. 2008. Pedoman Imunisasi di Indonesia, Jakarta: Satgas Imunisasi IDAI.

Satgas Imunisasi PP IDAI. 2011. Panduan Imunisasi Anak Mencegah Lebih Baik daripada Mengobati. Jakarta: IDAI.

Soetjiningsih. 2004. Tumbuh Kembang Anak. Jakarta: EGC.

Sugiyono. 2011. Metode Penelitian Kuantitatif Kualitatif dan $R \& D$. Bandung: Alfabeta.

Suriniah, 2008. Pintar Merawat Bayi 0-12 bulan, Gramedia Pustaka Utama: Jakarta.

Suyanto. 2008. Riset Kebidanan. Jogjakarta: Mitra Cendikia Pres.

Tirtarahardja. 2005. Pengantar pendidikan. Jakarta: Rineka Cipta.
Tupitu, F. 2007. Pengaruh konseling gizi dengan pengetahuan, asupan zat gizi, dan kadar gula darah penderita DM tidak tergantung insulin di Poliklinik Gizi. FKM Universitas Islam Jakarta. Jakarta.

Undang-Undang Kesehatan dan Rumah Sakit Nomor 36. 2009. Yogyakarta: Pustaka Yustisia.

Undang-Undang Sisdiknas No. 20. 2003. Jakarta: Pustaka Yustisia.

Wahab. 2002. Sistem Imun, Imunisasi dan Penyakit Imun. Jakarta: Widya Medika

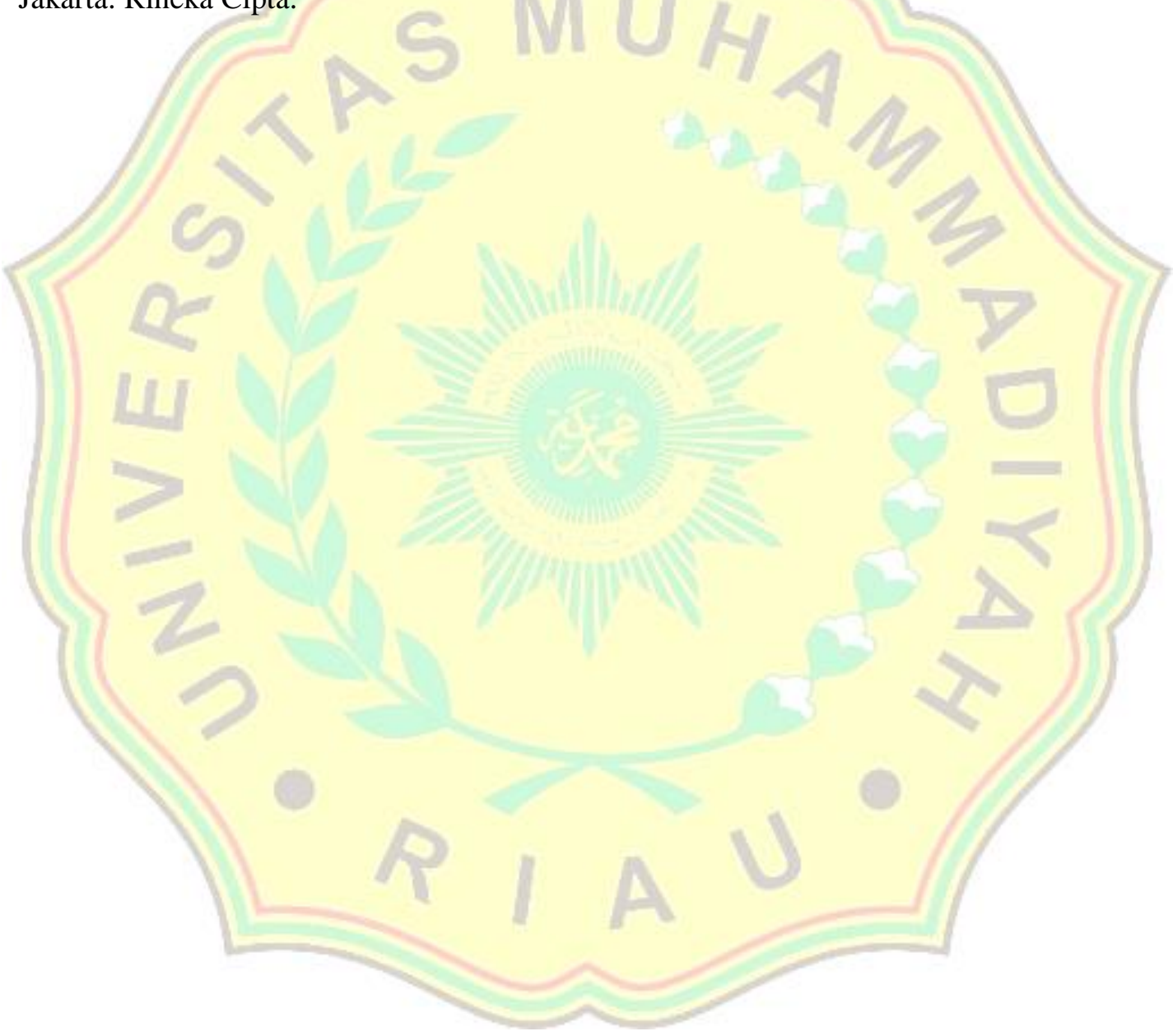

